\title{
ANALISIS KENDALA DAN MEDIA PEMBELAJARAN JARAK JAUH DI SEKOLAH PADA MASA PANDEMI
}

\section{FATAYAT RIDLO MINTARSIH}

SMK Negeri 12 Surabaya

e-mail: dramintarsih19@guru.smk.belajar.id

\begin{abstract}
ABSTRAK
Pelaksanaan pendidikan Jarak Jauh yang telah dilaksanakan selama masa pandemi COVID-19 telah merubah sistem pendidikan dengan media berbasis teknologi namun dalam pelaksanaanya terdapat kendala dan hambatan. Tujuan penelitian untuk mengetahui tentang media pembelajaran Jarak jauh yang diimplementasikan dalam sekolah dengan kendala yang dihadapinya. Penelitian ini menggunakan metode Studi Literature .yaitu dengan menganalisis berbagai refrensi dari artikel internasional, nasional, buku maupun sumber sejenis terkait implementasi media pembelajaran daring selama pandemi. Pembelajaran Jarak Jauh dengan menggunakan berbagai media pembelajaran menjadi solusi dalam mengaktifkan kegiatan belajar mengajar pada masa pandemi ini
\end{abstract}

Kata Kunci : Media Pembelajaran, PJJ, Studi Literature

\section{PENDAHULUAN}

Pembelajaran Jarak Jauh merupakan suatu hal yang sudah tidak asing lagi bagi dunia Pendidikan baik di Indonesia maupun di dunia Internasional sekaramg ini. Sejak adanya pandemi Covid 19, dunia dihadapkan masalah untuk menghadapi penyebaran virus Covid 19 dalam segala aktivitas kehidupan ekonomi, sosial, serta tidak terkecuali pula dalam dunia pendidikan, baik peserta didik maupun guru harus dihadapkan pada kenyataan untuk melakukan pembelajaran secara daring. Melalui surat edaran Kementrian Pendidikan dan Kebudayaan (Kemendikbud) tentang pencegahan penyebaran Corona Virus Disease (COVID19) di lembaga pendidikan. Melalui surat edaran tersebut pihak Kemendikbud memberikan instruksi kepada lembaga pendidikan untuk menyelenggarakan pembelajaran jarak jauh dan menyarankan peserta didik untuk belajar dari rumah masing-masing (https://pusdiklat.kemdikbud.go.id). Penyebaran Covid-19 yang semakin tidak terkendali menyebabkan pemerintah terpaksa untuk menutup sekolah-sekolah dan mendorong pembelajaran jarak jauh di rumah. Berbagai inisiatif dilakukan untuk memastikan kegiatan belajar tetap berlangsung meskipun tidak adanya sesi tatap muka langsung.

Pelaksanaan pembelajaran yang sebelumnya dilakukan dengan tatap muka beralih ke pembelajaran secara virtual dimana tidak secara nyata peserta didik bertatap muka dalam sebuah kelas tetapi melalui media online yang sudah banyak digunakan dalam aplikasi atau platform untuk melakukan pembelajaran secara online atau daring yang dilakukan di seluruh Lembaga Pendidikan di Indonesia. Penggunaan media teknologi, seperti smartphone, I-phone dan laptop sekarang digunakan secara luas untuk mendukung pembelajaran jarak jauh. Hal ini merupakan suatu revolusi pelaksanaan pembelajaran, mau tidak mau siap tidak siap baik pesrta didik maupun guru harus menggunakan media pembelajaran secara online seperti WhatsApp (WA), telegram,aplikasi zoom, Google Classroom ataupun media lainnya sebagai media pembelajaran Pemerintah juga telah berupaya membantu pembelajaran jarak jauh dengan menyediakan akun belajar seperti rumah belajar. Untuk melakukan pembelajaran online (PJJ) sangat dibutuhkan jaringan internet. Pada saat sekolah masih melakukan pembelajaran secara tatap muka jaringan internet hanya dipakai untuk mengirim data, mengakses internet untuk mencari informasi yang dibutuhkan sesuai dengan keperluannya masing masing, namun setelah adanya pembelajaran online maka keperluan jaringan internet sangatlah dibutuhkan untuk melakukan pembelajaran online. Pembelajaran jarak jauh dengan memanfaatkan jaringan internet sangat memungkinkan kendala tersendiri bagi Guru dan peserta didik yang tinggal di wilayah dengan keterbatasan jaringan internet, seperti di daerah atau desa terpencil. 
Adanya pandemi Covid-19 pembelajaran di daerah terpencil juga harus tetap berlangsung. Pembelajaran jarak jauh juga harus dilakukan. Pelaksanaan pembelajaran Jarak Jauh di kota akan berbeda dengan pembelajaran jarak jauh yang dilaksanakan di desa atau daerah terpencil. Pandemi COVID-19 telah memaksa sistem pendidikan melakukan pembelajaran jarak jauh (PJJ). Peristiwa ini rentan bagi peserta didik di daerah terdepan, Terluar, dan Tertinggal (3T) karena berpotensi kehilangan hak belajarnya (Arkiang,2021). Banyak kendala yang muncul dalam pelaksanaan pembelajaran jarak jauh (PJJ) di daerah terpencil. Menurut Kasdiah dalam situsnya https://sulteng.kemenag.go.id menyatakan bahwa pembelajaran online mengalami kesulitan dalam pembelajaran karena Signal/jaringan internet yang tidak bagus, karena masih kurangnya informasi dalam menggunakan teknologi maka siswa belum siswa belum dapat menggunakan aplikasi pembelajaran

Kendala-kendala yang dihadapi dalam pembelajaran jarak jauh yaitu keterbatasan SDM, keterbatasan sarana prasarana seperti laptop atau HP yang dimiliki orangtua peserta didik, kesulitan akses internet, kondisi listrik yang tidak stabil, dan keterbatasan kuota internet yang bisa disediakan oleh orangtua. Menteri pendidikan pada kegiatan Webinar Penyesuaian Kebijakan Pembelajaran di Masa Pandemi Covid-19, yang dilaksanakan secara virtual melalui Zoom dan disiarkan langsung dari kanal YouTube Kemendikbud RI menyatakan terdapat beberapa kendala yang dihadapi guru, orangtua, dan peserta didik selama PJJ setidaknya meliputi:

1. Guru mengalami hambatan dalam PJJ dan cenderung fokus kepada penuntasan kurikulum.

2. Waktu pembelajaran menjadi berkurang, sehingga guru tidak dapat memenuhi beban jam mengajarnya.

3. Guru mengalami kesulitan komunikasi dengan orangtua sebagai pembimbing peserta didik di rumah

4. Belum semua orangtua bersedia dan mampu mendampingi anak belajar di rumah karena ada tanggung jawab yang lain seperti urusan kerja, urusan rumah, dan sebagainya.

5. Orangtua mengalami kesulitan dalam memahami pelajaran dan memotivasi anak saat mendampingi belajar di rumah.

6. Peserta didik mengalami kesulitan untuk konsentrasi dalam belajar dari rumah dan mengeluhkan banyaknya penugasan soal dari guru.

7. Meningkatnya rasa stress dan jenuh akibat isolasi di rumah secara berkelanjutan berpotensi menimbulkan rasa cemas dan depresi bagi anak, akses ke sumber belajar baik disebabkan karena masalah jangkauan listrik atau internet, maupun dana untuk aksesnya.( https://www.stit-alkifayahriau.ac.id)

Berdasarkan permasalahan tersebut artikel ini berfokus pada bagaimana pelaksanaan Pembelajaran Jarak jauh dapat dilakukan disekolah sekolah yang banyak mengalami kendala permasalahan seperti yang telah jelaskan diatas oleh karena itu tujuan dari penulisan artikel ini Tulisan ini berusaha memberikan pandangan tentang penggunaan media pembelajaran Jarak jauh yang diimplementasikan dalam sekolah dengan kendala yang dihadapinya

\section{METODE PENELITIAN}

Tulisan ini tergolong atau termasuk dari hasil penelitian kajian pustaka. Menurut Danial dan Warsiah (2009:80) dalam situs https://elibrary.unikom.ac.id, Studi Literatur adalah merupakan penelitian yang dilakukan oleh peneliti dengan mengumpulkan sejumlah buku buku, majalah yang berkaitan dengan masalah dan tujuan penelitia. Dengan demikian dapat diketahui bahwa penelitian kajian pustaka adalah penelitian yang dilakukan dengan cara mengumpulkan, mengolah, dan menyimpulkan data yang sesuai dengan literatur-literatur yang mendukung yang berkaitan dengan permasalahan

Penelitian dengan menggunakan studi literatur ini dilakukan dengan tujuan untuk mengungkapkan berbagai teori-teori yang relevan dengan permasalahan yang sedang dihadapi/diteliti sebagai bahan rujukan dalam pembahasan hasil penelitian. Penelitian literatur merupakan penelitian yang mencari referensi teori yang relevan. Literatur yang digunakan 
berupa buku, artikel ilmiah yang berasal dari jurnal internasional maupun nasional. Literatur yang digunakan adalah literatur relevan dengan studi ini dan telah dicetak maupun dipublikasikandengan kasus atau permasalahan yang ditemukan yang memuat informasi mengenai permasalahan yang akan dibahas pada penelitian ini yaitu bagaimana pembelajaran jarak jauh itu dilaksanakan disekolah-sekolah. Tujuan tulisan ini adalah agar nantinya bisa menambah pengetahuan dan bermanfaat dalam pelaksanaan pembelajaran jarak jauh di sekolah sekolah

\section{HASIL DAN PEMBAHASAN}

Pembelajaran Jarak Jauh (PJJ) adalah proses belajar mengajar di mana pengajar dan peserta didik (mahasiswa) berada dalam lokasi atau tempat yang berbeda. Dengan kehadiran teknologi digital, saat ini PJJ dapat dilakukan dengan lebih mudah dan efektif (Lili Kasmini.2020). Pembelajaran jarak jauh merupakan sistem pembelajaran yang tidak berlangsung dalam satu ruangan dan tidak ada interaksi tatap muka secara langsung antara pengajar dan pembelajar Menurut Daryanto (2017) dalam Kurnia Dwi Setyaningsih, Karma Iswasta Eka, Badarudin(2021) menyatakan bahwa PJJ merupakan pembelajaran dengan menggunakan suatu media yang memungkinkan terjadinya interaksi antara pengajar dan pembelajar yang tidak bertatap muka secara langsung, dengan kata lain pembelajaran dilakukan oleh pendidik dengan peserta didik melalui platform yang digunakan pendidik dalam mengadakan interaksi untuk kebutuhan pembelajaran. Sedangkan menurut Sri Gusti dkk. (2020) Pembelajaran online merupakan pembelajaran tanpa tatap muka secara fisik namun tetap bisa bertatap muka secara virtual. Dalam hal ini pembelajaran tatap muka dilakukan melalui platform atau aplikasi seperti zoom, Google Meet Webex atau aplikasi yang lainnya sehingga guru bias menjelaskan pelajaran dengan tatap muka secara online, Sedangkan menurut Tesniyadi, 2018 dikutip dalam Aas Aliana Futriani Hidayah, Robiah Al Adawiyah, Prima Ayu Rizqi Mahanani alam Pembelajaran daring adalah proses pembelajaran yang menggunakan akses komputer dan jaringan internet untuk membantu proses interaksi dalam proses pembelajaran. Jaringan Internet merupakan kebutuhan utama dalam pembelajaran online, dengan menggunakan jaringan internet pendidik dan peserta didik dapat melakukan pembelajaran jarak jauh atau online sebagai solusi pembelajaran pada masa pandemic sesuai dengan anjuran pemerintah, walaupun dalam kenyataannya pelaksanaan pembelajaran daring banyak mengalami kendala bagi pendidik maupun peserta didik. Pendidik harus bisa menguasai platform pembelajaran yang digunakan dalam pembelajaran sedangkan peserta didik juga dituntut bisa mengikuti pembelajaran melalui platform yang di gunakan oleh pendidik. Kendala-kendala dalam pembelajaran Jarak Jauh atau online dialami hampir seluruh sekolahsekolah yang ada di Indonesia 


\begin{tabular}{|c|c|c|c|c|}
\hline $\begin{array}{l}\text { Judul,Penulis, } \\
\text { Tahun }\end{array}$ & $\begin{array}{l}\text { Lokasi/Tem } \\
\text { pat }\end{array}$ & $\begin{array}{l}\text { Kendala / hambatan } \\
\text { pembelajaran Jarak } \\
\text { jauh (online) }\end{array}$ & Metode & $\begin{array}{l}\text { Implementasi } \\
\text { Media } \\
\text { pembelajaran } \\
\text { Jarak Jauh (online) }\end{array}$ \\
\hline $\begin{array}{l}\text { analisis } \\
\text { Pembelajaran } \\
\text { Daring Selama } \\
\text { Pandemi } \\
\text { Covid-19 Di } \\
\text { Daerah 3t } \\
\text { (Nusa } \\
\text { Tenggara } \\
\text { Timur } \\
\text { Arkiang, } \\
\text { F/Jurnal } \\
\text { Pendidikan, } \\
\text { Vol 12, No 1 } \\
\text { (2021) }\end{array}$ & $\begin{array}{l}\text { Provinsi } \\
\text { NTT }\end{array}$ & $\begin{array}{l}\text { separuh lebih daerah } \\
\text { 3T sudah memiliki } \\
\text { jaringan internet, } \\
\text { tetapi kurang bisa } \\
\text { digunakan dengan } \\
\text { baik. Hal itu bisa jadi } \\
\text { disebabkan oleh } \\
\text { kekuatan sinyal yang } \\
\text { lemah, di samping } \\
\text { juga kurangnya } \\
\text { kemampuan sumber } \\
\text { daya manusianya } \\
\text { dalam mengakses } \\
\text { teknologi } \\
\text { Pendidikan Jarak Jauh } \\
\text { juga telah } \\
\text { menimbulkan bias } \\
\text { persoalan. Dari aspek } \\
\text { geografis telah } \\
\text { menimbulkan bias } \\
\text { antara Jawa dan luar } \\
\text { Jawa. Kemudian dari } \\
\text { sisi akses teknologi } \\
\text { dan ketersediaan } \\
\text { listrik, belajar dari } \\
\text { rumah ini telah } \\
\text { memunculkan bias } \\
\text { antara daerah } \\
\text { berkoneksi internet } \\
\text { lancar dan daerah } \\
\text { yang tidak terjangkau } \\
\text { jaringan internet sama } \\
\text { sekali, ataupun belum } \\
\text { teraliri listrik }\end{array}$ & $\begin{array}{l}\text { descriptiv } \\
\text { e content } \\
\text { analysis } \\
\text { study. }\end{array}$ & $\begin{array}{l}\text { Yang dilakukan oleh } \\
\text { pendidik dan peserta } \\
\text { didik, dengan } \\
\text { memanfaatkan } \\
\text { WhatsApp Group } \\
\text { (WAG) }\end{array}$ \\
\hline $\begin{array}{l}\text { Analisis } \\
\text { Pelaksanaan } \\
\text { Pembelajaran } \\
\text { Jarak Jauh } \\
\text { Di Sd Negeri } \\
\text { Karangrena 03, } \\
\text { Kurnia Dwi } \\
\text { Setyaningsih } 1 \text {, } \\
\text { Karma Iswasta } \\
\text { Eka² }^{2} \\
\text { Badarudin }^{3}, \\
\text { 2001 }\end{array}$ & Purwokerto & $\begin{array}{l}\text { sebagian orang tua } \\
\text { yang memiliki } \\
\text { pekerjaan tetap, tidak } \\
\text { bisa selalu } \\
\text { mendampingi peserta } \\
\text { didik dalam kegiatan } \\
\text { PJJ, karena memiliki } \\
\text { tugas dan tanggung } \\
\text { jawab dalam } \\
\text { pekerjaannya. }\end{array}$ & $\begin{array}{l}\text { Kualitatif } \\
\text { deskriptif. }\end{array}$ & $\begin{array}{l}\text { menerapkan metode } \\
\text { pembelajaran daring } \\
\text { dan luring. } \\
\text { Pembelajaran daring } \\
\text { guru selalu } \\
\text { menggunakan } \\
\text { whatsapp group } \\
\text { untuk } \\
\text { memberikan presensi } \\
\text { pada peserta didik } \\
\text { serta mengirimkan } \\
\text { tugas dan materi }\end{array}$ \\
\hline
\end{tabular}




\begin{tabular}{|c|c|c|c|c|}
\hline & & $\begin{array}{l}\text { Kedua yaitu orang tua } \\
\text { memerlukan } \\
\text { penjelasan lebih } \\
\text { terkait dengan tugas } \\
\text { yang diberikan kepada } \\
\text { peserta didik. } \\
\text { Ketiga yaitu motivasi } \\
\text { belajar peserta didik } \\
\text { menjadi menurun } \\
\text { karena kurang } \\
\text { pendampingan dari } \\
\text { orang tua, dan tidak } \\
\text { belajar secara } \\
\text { langsung dengan guru }\end{array}$ & & $\begin{array}{l}\text { Pembelajaran luring } \\
\text { dilaksanakan sebagai } \\
\text { pembelajaran } \\
\text { tambahan yaitu } \\
\text { dengan } \\
\text { guru membagi } \\
\text { kelompok belajar } \\
\text { sehingga } \\
\text { guru dapat door to } \\
\text { door mendatangi } \\
\text { peserta didik. Hal ini } \\
\text { bertujuan agar } \\
\text { peserta didik } \\
\text { semangat dalam } \\
\text { proses } \\
\text { pembelajaran. } \\
\text { Guru di SDN } \\
\text { Karangrena } 03 \\
\text { menggunakan model } \\
\text { PJJ dengan } \\
\text { memberikan materi } \\
\text { secara online pada } \\
\text { peserta didik } \\
\text { kemudian di } \\
\text { download dan } \\
\text { dipelajari secara } \\
\text { manual (offline), } \\
\text { selain itu guru } \\
\text { memberikan materi } \\
\text { pembelajaran } \\
\text { secara online dan } \\
\text { peserta didik } \\
\text { mempelajari secara } \\
\text { online }\end{array}$ \\
\hline $\begin{array}{l}\text { Evaluasi } \\
\text { Pembelajaran } \\
\text { Daring Selama } \\
\text { Pandemi } \\
\text { Covid-19 Di } \\
\text { Kecamatan } \\
\text { Bulukerto } \\
\text { Wonogiri, } \\
\text { Rika Yuni } \\
\text { Ambarsari, } \\
\text { Jurnal Mitra } \\
\text { Swara } \\
\text { Ganesha, } 2021\end{array}$ & $\begin{array}{l}\text { Bulukerto } \\
\text { Wonogiri }\end{array}$ & $\begin{array}{l}\text { Pertama, dari peserta } \\
\text { didik ada beberapa } \\
\text { anak yang tidak } \\
\text { memiliki gawai(HP), } \\
\text { terkendala koneksi } \\
\text { internet } \\
\text { orang tua hanya dapat } \\
\text { mendampingi ketika } \\
\text { malam hari. } \\
\text { keterbatasan koneksi } \\
\text { internet, } \\
\text { beberapa orang tua } \\
\text { yang tidak paham } \\
\text { dengan teknologi. }\end{array}$ & $\begin{array}{l}\text { kualitatif } \\
\text { dengan } \\
\text { menggun } \\
\text { akan } \\
\text { metode } \\
\text { survei } \\
\text { yang } \\
\text { dilakukan } \\
\text { secara } \\
\text { online }\end{array}$ & $\begin{array}{l}\text { Model } \\
\text { pembelajaran } \\
\text { daring yang } \\
\text { menjadi pilihan } \\
\text { pertama, yaitu } \\
\text { sebanyak 100\% } \\
\text { guru-guru } \\
\text { menggunakan } \\
\text { fasilitas WA atau } \\
\text { (WhatsApps) } \\
\text { dimana guru } \\
\text { membuat } \\
\text { WhatsApps group } \\
\text { sehingga semua } \\
\text { siswa dapat terlibat } \\
\text { dalam grup. Tugas- }\end{array}$ \\
\hline
\end{tabular}




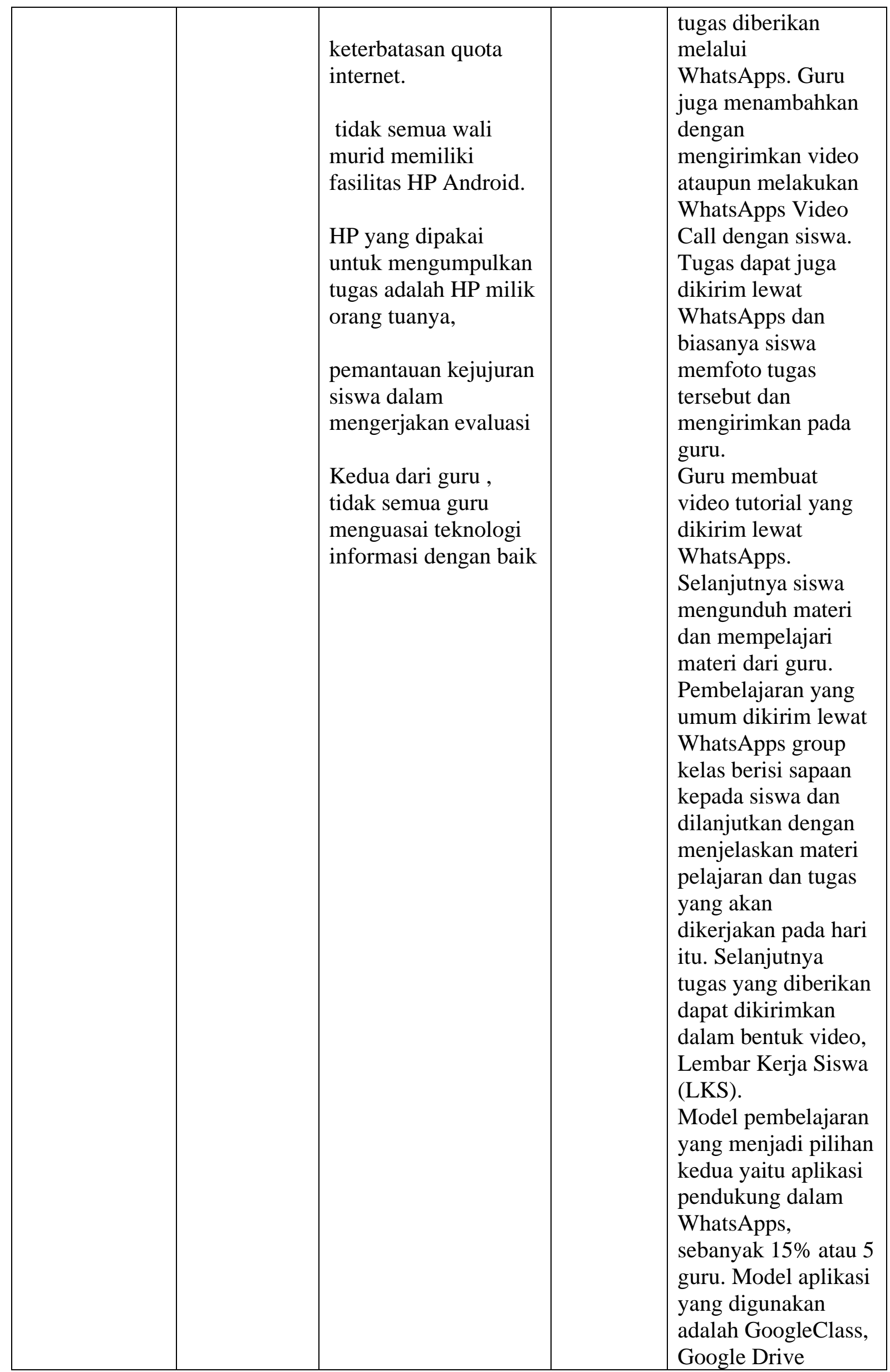




\begin{tabular}{|c|c|c|c|c|}
\hline & & & & $\begin{array}{l}\text { ataupun Google } \\
\text { Form } \\
3 \text { guru menggunakan } \\
\text { Google Form untuk } \\
\text { tugas dan melakukan } \\
\text { evaluasi. } \\
\text { mengunggah video } \\
\text { agar dapat ditonton } \\
\text { oleh siswa } \\
\text { Pilihan aplikasi ke- } \\
\text { tiga yang lain } \\
\text { adalahGoogle Form } \\
\text { sebanyak 12\% atau } \\
8 \text { guru. } \\
\text { Pemanfaatan } \\
\text { Google Form yaitu } \\
\text { untuk LKS siswa. } \\
\text { Pilihan aplikasi ke- } \\
\text { empat yang } \\
\text { digunakan adalah } \\
\text { Youtube } \\
\text { (mengunggah video } \\
\text { pembelajaran) yang } \\
\text { digunakan } \\
\text { sebanyak } 7 \% \text { atau } \\
\text { 5guru. } \\
\text { Aplikasi yang ke- } \\
\text { lima adalah aplikas } \\
\text { Zoom Cloud } \\
\text { Meeting yang } \\
\text { dimanfaatkan } 3 \% \\
\text { atau } 2 \% \text { guru untuk } \\
\text { menjelaskan materi } \\
\text { baru yang diangap } \\
\text { sulit. }\end{array}$ \\
\hline $\begin{array}{l}\text { Adaptasi } \\
\text { Sekolah } \\
\text { Dalam } \\
\text { Mengimple } \\
\text { mentasikan } \\
\text { Pembelajara } \\
\text { n Jarak Jauh } \\
\text { Pada Masa } \\
\text { Pandemi } \\
\text { Covid-19 } \\
\text { (Studi } \\
\text { Kasus Smp } \\
\text { Muhammad } \\
\text { iyah } \\
\text { Karanggene }\end{array}$ & $\begin{array}{l}\text { SMP } \\
\text { Muhammadi } \\
\text { yah } \\
\text { Kecamatan } \\
\text { Karanggene } \\
\text { ng } \\
\text { Kabupaten } \\
\text { Lamongan } \\
\text { Provinsi } \\
\text { Jawa Timur }\end{array}$ & $\begin{array}{l}\text { terdapat guru yang } \\
\text { memiliki kompetensi } \\
\text { kurang bagus di } \\
\text { bidang pemanfaatan } \\
\text { teknologi informasi } \\
\text { dalam pembelajaran, } \\
\text { kurang fokusnya } \\
\text { peserta didik sehingga } \\
\text { memerlukan } \\
\text { pemantauan orang tua } \\
\text { dalam proses } \\
\text { pembelajaran, } \\
\text { tuntutan selalu } \\
\text { tersedianya jaringan } \\
\text { dan kuota internet }\end{array}$ & $\begin{array}{l}\text { kualitatif } \\
\text { lapangan } \\
\text { (field } \\
\text { research) }\end{array}$ & $\begin{array}{l}\text { melakukan } \\
\text { perubahan } \\
\text { manajemen } \\
\text { pendidikan dengan } \\
\text { sistem } \\
\text { pembelajaran jarak } \\
\text { jauh, } \\
\text { memaksimalkan } \\
\text { peran kepala } \\
\text { sekolah, waka } \\
\text { kurikulum dan } \\
\text { guru, melakukan } \\
\text { interaksi secara } \\
\text { kontinu dengan } \\
\text { wali murid dan }\end{array}$ \\
\hline
\end{tabular}


Vol 1. No 1. Agustus 2021, e-ISSN : 2807-1808 | P-ISSN : 2807-2294

\begin{tabular}{|c|c|c|c|c|}
\hline $\begin{array}{l}\text { ng } \\
\text { Kabupaten } \\
\text { Lamongan), } \\
\text { S Sumarno - } \\
\text { Jurnal } \\
\text { Tarbiyah } \\
\text { dan Ilmu } \\
\text { Keguruan } \\
\text { Borneo, } \\
\text { 2020 - } \\
\text { core.ac.uk }\end{array}$ & & $\begin{array}{l}\text { baik bagi peserta didik } \\
\text { maupun guru }\end{array}$ & & $\begin{array}{l}\text { mengoptimalkan } \\
\text { penggunaan } \\
\text { aplikasi WhatsApp } \\
\text { guru terlebih } \\
\text { dahulu meminta } \\
\text { membaca bacaan } \\
\text { yang ada di Lembar } \\
\text { Kerja Siswa (LKS) } \\
\text { masing-masing } \\
\text { murid. Setelah itu } \\
\text { guru meminta } \\
\text { untuk mengerjakan } \\
\text { soal dan Latihan } \\
\text { yang ada di LKS } \\
\text { tersebut. Jika sudah } \\
\text { selesai kemudian } \\
\text { guru meminta } \\
\text { untuk } \\
\text { mengumpulkan } \\
\text { hasil kerja siswa } \\
\text { tersebut melalui } \\
\text { grup dan terakhir } \\
\text { guru memberikan } \\
\text { penilaian sebagai } \\
\text { media komunikasi } \\
\text { dalam } \\
\text { pembelajaran }\end{array}$ \\
\hline $\begin{array}{l}\text { Implementa } \\
\text { si } \\
\text { Pembelajara } \\
\text { n Daring } \\
\text { (Program } \\
\text { BDR) } \\
\text { Selama } \\
\text { Pandemi } \\
\text { Covid-19 di } \\
\text { Provinsi } \\
\text { Jawa Barat, } \\
\text { Rina } \\
\text { Mutaqinah1, } \\
\text { Taufik } \\
\text { Hidayatulla } \\
\text { h2, - Jurnal } \\
\text { PETIK } \\
\text { Volume 6, } \\
\text { Nomor 2, } \\
\text { September } \\
\text { 2020--86 }\end{array}$ & $\begin{array}{l}\text { Provinsi } \\
\text { Jawa Barat }\end{array}$ & $\begin{array}{l}\text { kendala yang dihadapi } \\
\text { guru berupa } \\
\text { keterbatasan } \\
\text { kuota/jaringan, } \\
\text { kesulitan mengontrol } \\
\text { siswa sedangkan bagi } \\
\text { orang tua akses } \\
\text { internet dan } \\
\text { terbatasnya fasilitas } \\
\text { gadget serta kesulitan } \\
\text { mengatur waktu dan } \\
\text { proses mendampingi } \\
\text { anak belajar; }\end{array}$ & $\begin{array}{l}\text { metoda } \\
\text { survey, } \\
\text { menurut } \\
\text { Scheuren } \\
\text { kata } \\
\text { survei } \\
\text { paling } \\
\text { sering } \\
\text { digunaka } \\
\text { n untuk } \\
\text { menjelask } \\
\text { an } \\
\text { metode } \\
\text { pengump } \\
\text { ulan } \\
\text { informasi } \\
\text { dari } \\
\text { sampel } \\
\text { individu }\end{array}$ & $\begin{array}{l}\text { Persiapan dan } \\
\text { perencanaan, } \\
\text { dilakukan melalui } \\
\text { surat edaran } \\
\text { Mendikbud dan } \\
\text { Pemda disambut } \\
\text { sekolah dan } \\
\text { diteruskan dengan } \\
\text { melakukan } \\
\text { sosialisasi kepada } \\
\text { warga sekolah dan } \\
\text { orang tua melalui } \\
\text { media sosial, guru } \\
\text { membuat } \\
\text { perencanaan BDR } \\
\text { melalui daring } \\
\text { dengan aplikasi; 2). } \\
\text { Proses, media dan } \\
\text { sumber } \\
\text { pembelajaran, } \\
\text { dilakukan secara } \\
\text { daring melalui } \\
\text { media sosial, } \\
\text { Facebook, WA, IG, }\end{array}$ \\
\hline
\end{tabular}


Berdasarkan 5 artikel diatas masing masing memiliki hambatan dalam pelaksanaan pembelajaran jarak jauh (online) pada artikel pertama oleh Arkiang F Pembelajaran jarak jauh menjadi solusi untuk menggerakkan kegiatan pembelajaran walaupun lembaga pendidikan telah menerapkan work from home. Namun, teknik pembelajaran virtual ini sangat penting untuk di evaluasi, karena koneksi jaringan internet menjadi salah satu kendala yang dihadapi peserta didik yang tempat tinggalnya sulit untuk mengakses internet, apalagi peserta didik tersebut tempat tinggalnya di daerah pedesaan, terpencil dan tertinggal

Dalam artikel ke 2 oleh , Kurnia Dwi Setyaningsih ${ }^{1}$, Karma Iswasta Eka², Badarudin ${ }^{3}$ yang menghadapi kendala atau yang menjadi hambatan adalah orang tua harus menambah waktu untuk mendampingi anak-anak. Sedangkan dari segi guru, guru menjadi melek teknologi dan dituntut untuk belajar banyak hal kususnya pembelajaran berbasis daring. Sistem pembelajaran daring ini dapat dijadikan sebagai model dalam melakukan pembelajaran selanjutnya. Model pembelajaran yang menjadi pilihan yaitu menggunakan WhatsApps, sebanyak $15 \%$ atau 5 guru. Model aplikasi yang digunakan adalah Google Classroom, Google Drive ataupun Google Form. Penggunaan Google Form digunakan untuk tugas dan melakukan evaluasi. Tambahan yang lainnya adalah Youtube yaitu dengan mengunggah video agar dapat ditonton oleh siswa. Dalam penelitian ini terdapat 3 guru menggunakan fasilitas tersebut. Guru juga menggunakan aplikasi Zoom dan Google Classroom yang hanya dilakukan dalam satu pekan sekali dengan alasan karena banyak orang tua yang masih bekerja.

Dalam artikel ke 3 , oleh Rika Yuni Ambarsari dijelaskan bahwa Whatsapp (WA) merupakan aplikasi yang paling banyak digunakan oleh semua guru dalam pembelajaran daring, dengan media WA guru pendidik bisa melakukan video call, bisa mengirim materi, mengirim dan mengumpulkan tugas. WhatsApp bisa dikirimkan gambar, voice note hingga vidio. Seperti yang dikemukakan oleh (Pertiwi, 2020 dalam Mirzon Daheri , Juliana , Deriwanto , Ahmad Dibul Amda) WhatsApp juga aplikasi dengan jumlah pengguna yang sangat besar Kemudian urutan yang ke 2 ada beberapa guru selain menggunakan WA juga menggunakan aplikasi pendukung lain yaitu GoogleClass, Google Drive ataupun Google Form juga menggunakan youtube, kemudian urutan ke 3 menggunakan google form diikuti urutan ke 4 menggunakan youtube sedangkan zoom adalah aplikasi yang paling sedikit digunakan oleh pendidik. Angkan yang menjadi hambatan atau kendala yaitu kurangnya waktu yang diperlukan orang tua dalam mendampingi anak-anak, belum juga dihadapkan tentang masalh kuota internet serta adanya kendala sinyal ketika melakukan pembelajaran jarak jauh. Sedangkan dari segi guru, guru menjadi melek teknologi dan dituntut untuk belajar banyak hal kususnya pembelajaran berbasis daring

Dalam artikel ke 4 oleh sumarno hambatan dan kendala yang dihadapi yaitu masih ada guru yang memiliki kompetensi kurang bagus dibidang pemanfaatan teknologi informasi dalam pembelajaran jarak jauh, kurang fokusnya peserta didik dalam melakukan pembelajaran jarak jauh sehingga memerlukan pemantauan dan pengawasan orang tua dalam proses pembelajaran Jarak Jauh , tersedianya jaringan dan kuota internet baik bagi murid maupun guru merupakan kebutuhan utama dalam melakukan pembelajaran jarak jauh. Sekolah mengadaptasi pembelajaran jarak jauh dengan melakukan perubahan manajemen pendidikan dengan system pembelajaran jarak jauh, memaksimalkan peran kepala sekolah, waka kurikulum dan guru, melakukan interaksi secara continue dengan wali siswa dan mengoptimalkan penggunaan aplikasi WhatsApp sebagai media komunikasi dalam pembelajaran.

Dalam artikel ke 5 oleh Rina Mutaqinah1, Taufik Hidayatullah2 dijelaskan bahwa media yang digunakan guru dalam melaksanakan pembelajaran daring adalah media sosial seperti Fb, IG,WA sebesar 90,1\% dan media elektronik seperti TVRI, radio dan video 90\%. Kendala yang lain yaitu Sebagian besar orang tua $(78,8 \%)$ kesulitan dalam hal mengatur waktu bekerja di rumah dan mendampingi anaknya Belajar dari rumah. 


\section{KESIMPULAN}

Pelaksanaan pembelajaran jarak jauh yang merupakan solusi pembelajaran dalam masa pandemi yang dalam pelaksanaannya di sekolah banyak mengalami hambatan atau kendala kendala diantaranya yaitu datang dari peserta didik yang tidak mempunyai HP, belum ada aliran listrik (yang ada di pedesaan), kendala kuota internet, kendala sinyal, juga kendala orang tua peserta didik yang kurang memahami tugas yng diberikan melalui daring atau online, sedangkan kendala dari guru, kurang adanya kemampuan dalam menguasai mdia pembelajaran daring.

Pemakaian media pembelajaran jarak jauh atau online yang paling banyak digunakan yaitu memakai aplikasi Whatsapp banyak digunakan untuk berinteraksi dalam pemblajaran jarak jauh, selanjutnya diikuti dengan pemakaian Google form dan google doc.juga sebagai pendukung tambahan menggunakan video di youtube serta sebagian juga menggunakan google classroomm.

Dalam menghadapi berbagai kendala yang ada dalam pelaksaaan Jarak Jauh sebagai langkah yang ditempih pada masa pandemi , maka berbagai sekolah menerapkan berbagai media pembelajaran jarak jauh dan meningkatkan kemampuan pendidik dalam menggunakan media pembelajaran jarak jauh. Dengan demikian bisa dijadikan bahan evaluasi dalam pebaikan pembelajarn jarak jauh yang lebih baik dan efektif

\section{DAFTAR PUSTAKA}

Aas Aliana Futriani Hidayah, Robiah Al Adawiyah, Prima Ayu Rizqi Mahanani Efektivitas 2020 Pembelajaran Daring Di Masa Pandemi Covid-19 dari Jurnal Penelitian Ilmu Sosial Vol. 21 No.2

ADAPTASI Sekolah Dalam Mengimplementasikan Pembelajaran Jarak Jauh Pada Masa Pandemi Covid-19 (Studi Kasus Smp Muhammadiyah Karanggeneng Kabupaten Lamongan) Sumarno Institut Agama Islam Negeri Samarinda Jl. H. A. M. Rifaddin, Harapan Baru, Kec Loa Janan Ilir Samarinda, Kalimantan Timur

Arkiang, Fajeri. (2010). "Analisis Pembelajaran Daring Selama Pandemi Covid-19 Di Daerah 3t (Nusa Tenggara Timur)". Jurnal Pendidikan: https://jp.ejournal.unri.ac.id

Gusti Sri dkk.(2020). Belajar Mandiri:Pembelajaran Daring di Tengah Pandemi Covid-19. Yayasan Kita Menulis Jurnal Tarbiyah \& Ilmu Keguruan (JTIK) Borneo Volume I No.2, 2020 E-ISSN: 2714-6030

Kasmini, Lili dkk. (2020). Buku Pedoman Implementasi PJJ. Banda Aceh : STKIP BBG

Kurnia Dwi Setyaningsih, Karma Iswasta Eka, Badarudin. (2021). Analisis Pelaksanaan Pembelajaran Jarak Jauh Di Sd Negeri Karangrena 03. Jurnal Riset Pendidikan Dasar e ISSN: 2723-8660

Kusdiah. (2021). "Dampak Pembelajaran Online di Wilayah terpencil” Kementrian Agama Sulawesi Tengah Mei 2021

Mirzon Daheri., Juliana., Deriwanto., Ahmad Dibul Amda. (2020). Efektifitas WhatsApp sebagai Media Belajar Daring. Jurnal Basicedu Volume 4 Nomor 4 Halm. 775 - 783

Rina Mutaqinah, Taufik Hidayatullah. (2020). Implementasi Pembelajaran Daring (Program BDR) Selama Pandemi Covid-19 di Provinsi Jawa Barat. Jurnal PETIK, Volume 6, Nomor 2, September 2020

Yuni Ambarsari. (2021). Evaluasi Pembelajaran Daring Selama Pandemi Covid-19 Di Kecamatan Bulukerto Wonogiri. Jurnal Mitra Swara Ganesha, Vol. 8 No. 1 (2021) 